\title{
The Trope of Displacement, the Disruption of Space: Cuba, a Moveable Nation ${ }^{81}$
}

\author{
How many doors do you have to knock on before you find your own?
}

(Rabindranath Tagore)

Where is the middle of the world? Here and elsewhere.

(Old Irish Proverb)

Migration, Søren Frank observes, is the defining characteristic of modern life (Salman). Focusing primarily on the work of Salman Rushdie, Frank examines the mutually dependent phenomena of migration, globalization, and cosmopolitanism. In "Step Across This Line," he points out, Rushdie describes the migrant as a person "without frontiers," an "archetypal figure of our age," who somehow defies the laws of gravity. The migrant "perform[s] the act of which all men anciently dream," Rushdie claims, "the thing for which they envy the birds; that is to say, we have flown" (qtd. in Frank, “Globalization" 111).

Undergirding Frank's exploration is a particular idea of weightlessness, first developed by Hans Ulrich Gumbrecht in his seminal essay "A Negative Anthropology of Globalization.” In "Globalization, Migration Literature, and the New Europe” Frank observes that Gumbrecht "initially distills two key characteristics: the increasing amount of information available to practically all human beings"-a result of the electronic age and ever increasing access to social media-and the idea that "this information (and its circulation)" becomes increasingly "detached from particular physical spaces” (107). Inspired by Gumbrecht's characterization of globalization as a growing spacelessness-with its attendant elimination of the dimension of spaceFrank posits what he terms the "double movement of elimination and recuperation of space," which points toward an idea of cosmopolitanism distinguished by a "growing independence of particular spaces," which are simultaneously characterized by "reactions of inertia [that] make them reconnect with dimensions of space" ("Globalization” 110).

Although traditional definitions of the cosmopolitan hint at the possibility of suspending the dimension of spatiality and allowing the paradoxical concept that one can simultaneously belong everywhere and nowhere-a kind of cultural or ethnic weightlessness, so to speak-post-1959 Cuban political discourse on both sides of

81 Portions of this essay are taken from my monograph Cuban Artists Across the Diaspora: Setting the Tent Against the House (2011) and are reprinted with the exclusive permission of the U of Texas P. 
the Florida Straits has tended to be nationalistic and territorial and to make nativist claims to authentic cultural or national identity. Dating back to the nineteenth century, dominant Cuban diasporic discourse frequently frames the condition of exile in absence-that absence is the island. Certain strains of this discourse share with other diasporic articulations the impulse to idealize the past and express an idealized, nostalgic vision of home and homeland as a fixed and unchanging physical place of origin. Adhering to the teleology of origin and return, another common feature they share is the tendency to describe the experience of displacement according to the binary of being un-homed/constructing a temporary "home away from home" (Clifford; Saffran).

The conjoined ideas of physical displacement and movement are implicit in the diasporic condition; however, in the particular case of Cuba, they bespeak a pattern of in-migration and out-migration that traces back over centuries and is framed primarily by the island's colonial history. ${ }^{82}$ Given its strategic geographical location, Cuba has always been, preeminently, a point of confluence; a site of convergences; a place of migratory interactions; and a circuit and receptacle for all manner of exchanges, some of which pre-date the first Spanish colonial interventions. ${ }^{83}$ Not unlike other Caribbean islands, it has been in motion for centuries, both physically and culturally. As a result, Cuban culture is stratified and striated by multiple and varied influences; and the watery, porous borders that circumscribe the island suggest perennial fluidity, constant motion, and cross-pollination. In this respect, Cuban culture is eclectic and cosmopolitan.

Just as generations of Cubans have absorbed and been transformed by the diverse presences that inhabited the island at various junctures, Cuba can be best understood as a moveable nation-rather than a static or fixed entity-a traveling, prismatic site of rupture and continuity resulting from continuous out-migrations and scatterings. Rooted in both the Indigenous and colonial pasts, the realities of migration and exile $^{84}$ continue to inform contemporary Cuban history and are the underlying condi-

82 Though I generally consciously avoid the notion that the Cuban case is exceptional, in part because any discussion of exceptionalism becomes enmeshed inevitably in the larger context of US race and class politics, the post-1959 scattering tends to draw attention as a result of some of the factors that distinguish it from other diasporic experiences: 1) its volume and longevity; 2) the idea that a majority of Cubans left the island-either voluntarily or forcibly-under varying degrees of duress and, therefore, cannot or will not return; 3) and the fact that the largest sector of the exile population resides in South Florida in close geographical proximity to the homeland.

83 Pre-colonial Cuba was frequently the destination point, for example, for Caribs canoeing to the island from present-day Venezuela and Colombia. Indigenous groups, such as the Arawaks, migrated among the islands in the Caribbean.

84 Following the conclusion of the Ten Years War (1868-1878), a cohort of separatists, as well as thousands who sought work outside of Cuba because of the economic depression that occurred in the aftermath of the war, left the island. Exiled separatists established themselves in various parts of the United States, Latin America, and Europe. The most prominent figure in this struggle was the re- 
tions that inflect the Cuban experience writ large. In consequence, as art critic and poet Ricardo Pau-Llosa observes, "exile-indeed displacement-has been a constant in the development of the Cuban [cultural] imagination for ... centuries" (41).

Any profound understanding of the themes of displacement and cultural transference or transformation in respect to the island and its various diasporas must, therefore, move away from the idea perpetuated in dominant political and diasporic discourse of Cuba as a unified category of analysis. The realities of modern-day globalization, as Frank and others remind us-with its increasing technological exchanges and the forcible and voluntary circulation of people, culture, and all things popularprevent us from maintaining stationary or exclusivist paradigms when analyzing transnational, cosmopolitical diasporic formations (to borrow Cheah and Robbins' term). Instead, as Ella Shohat suggests, we must begin with the premise that all nations "exist not as hermetically sealed entities but, rather, as part of a permeable interwoven relationality" (2). The challenge then is to speak of Cuba and Cuban cultural expression (which includes the work of diasporic artists) within a kaleidoscopic framework (to borrow Ella Shohat's terminology) as a series of communities (located both inside and outside the island), which are "in relation to one another yet whose positions are not identical” (3).

Both my creative and scholarly work on the Cuban diaspora aim to envision a more nuanced, malleable paradigm regarding cosmopolitical diasporic identity formation, which moves away from essentialist, territorially- and linguistically-based concepts of racial, ethnic, national, or cultural identification. Works such as ReMembering Cuba: Legacy of a Diaspora, Cuba: Idea of a Nation Displaced, The Pearl of the Antilles, and Cuban Artists Across the Diaspora: Setting the Tent Against the House (which approaches diasporic identity through the lens of visual culture) explore the dual themes of migration identity and cultural exchange within a global, transnational framework and posit a more creatively unstable theoretical approach, which simultaneously takes account of the fluid and shifting aspects of situated or contextual subjectivity, yet remains rooted in the local and the historical. Unlike Salman Rushdie's bodiless migrant, whom the author depicts as detached from space and defying the roots of belonging, my critical writing postulates a cosmopolitical poetics of movement and indeterminacy, which is simultaneously and paradoxically rooted and migratory. ${ }^{85}$ Although it acknowledges the significance of the situational and

nowned poet, journalist, and philosopher José Martí, the leader of the Partido Revolucionario Cubano y Puertorriqueño (Cuban and Puerto Rican Revolutionary Party).

85 In his discussion of Salman Rushdie, Søren Frank points out that the former deems belonging and rootedness as "a conservative myth, designed to keep us in our places" (Shame 86). Rushdie's concept is liberating, Frank observes, for "what follows is the freedom to flee and to fly, and a liberation from everything that ties us down and restricts our movement." Many contemporary characters in migrant literature, he continues, embody the practice of weightlessness, and consequently present a new image of what it means to be human. "At first glance then," Frank concludes, "the migrant is 
contextual-of place and locality-the approach to diasporic identity formation postulated in this work ultimately positions itself against the impulse to locate Cuba solely according to geographical coordinates, thereby bypassing the correspondent essentialist discourses, which Shohat alludes to, that propose a closed or static definition of nationhood or national and cultural affiliation.

The art exhibition CAFÉ: The Journeys of Cuban Artists-curated primarily by Cuban artist Leandro Soto-provides an ideal metaphor through which to explore the paradoxes of migratory stability and stable mobility ${ }^{86}$ inherent in the Cuban diasporic condition. ${ }^{87}$ Unconventional in every respect, $C A F E$ is a radically inclusive, itinerant, and evolving art exhibition, which features alternating, multi-generational groups of Cuban diasporic artists conceived or born on or off the island. The participating artists work with a wide range of art media and techniques; recent manifestations of the exhibition have included poetry and fiction readings, lectures and roundtable discussions, dance and performance art, theatrical presentations, and traditional and original music composed by both Cuban and North American artists.

$C A F E$ testifies to a long tradition of Cuban art that continues to flourish outside the island, as well as the idea that Cuba's cultural continuity has always depended on a process of translation, absorption, and transformation that has occurred in this context of rupture and movement. All of the participating artists in $C A F E$ are, to varying degrees, visibly influenced by the new physical environments and cultural contexts in which they are working. However, their work simultaneously conserves a series of identifiable Cuban cultural elements-something that Cuban theorist and writer Antonio Benitez-Rojo referred to as the ancient dynamics of the island's variegated cultural roots and turbulent history-which are re-inscribed and transformed in new contexts (Benítez-Rojo). This historical reality, which provides the contextual framework for their art, has engendered a particular form of cosmopolitanism that not only "accommodates historical juncture," as Aparita Nanda describes (see her

the very incarnation of homo globalicus, that is, a gravity conquering bird unmoored from the Earth. If the migrant is a weightless and bodiless person detached from any local physical space, then he or she seems to fit well into what Gumbrecht refers to as yet another significant phenomenon of globalization that affects human lives, namely "the emergence and steady growth of a specific space-a 'network of channels' would be a good metaphor-that is immune to all local specifications and flavors" (Frank, Salman 234).

86 I am intentionally borrowing Eric Gary Anderson's terminology. For more information see E. G. Anderson (19).

$87 C A F E$ - an acronym for Cuban American Foremost Exhibitions-is curated by Leandro Soto and directed by his wife Grisel Pujalá. CAFÉ disrupts traditional Western modes of curating art exhibits. Rather than having a fixed set of showings in predetermined institutional locations, the exhibit is itinerant and ongoing; its location is unplanned in advance and may be presented in a wide range of venues. In other words, the curator, Cuban artist Leandro Soto, does not know where the next showing will be located, and he does not have a fixed idea regarding whom he will include in future exhibits. See O'Reilly Herrera, Cuban Artists (ch. 2), for a more detailed discussion. 
chapter in this collection), by implicitly acknowledging rupture and displacement, but also simultaneously admits the possibility of rootedness in new physical and cultural contexts, as well as fortuitous cultural exchange.

$C A F E$ artists such as José Bedia and Leandro Soto-both of whom were in the seminal group Volumen Uno-embody this cosmopolitan-cosmopolitical tendency to absorb newness into their work, yet simultaneously maintain a connection with their cultural roots. ${ }^{88}$ Their art becomes what Homi K. Bhabha characterizes throughout The Location of Culture as an unhomely space of intervention, which renders asymmetrical past, present, and future, and disrupts the paradigm of center, boundary, and frontier. Fundamental to their artmaking is this process of absorption, translation, and transformation described above, which fundamentally bespeak Bhabha's concepts of contemporaneity and trans- or multi-locality. Disrupting the temporal, situational, linear, and ultimately allegorical nature of nationalist discourse, Bhabha's conceptualization of diasporic cultural expression proposes the possibility of crosstemporality, which seeks to displace "the historicism that has dominated the nation as a cultural force," and expose what he describes as "the profound limitations of a consensual and collusive enunciation of cultural community" (140, 200-204). When approaching the diasporic experiences and all of their various articulations from this perspective, Bhabha observes that political borderlines, boundaries, and borderlands are not "that at which something stops," but rather, that from which something begins its "presencing" $(1,7){ }^{89}$

Visually embodying Bhabha's concepts of cross-temporality and multi-locality, José Bedia's art incorporates a conceptual, anthropological approach, which puts into relief cultural resonances as opposed to differences. Representing what Cuban art critic Gerardo Mosquera terms "another form of decentering," the artist draws from the content of African- and Indigenous-based worldviews of religious belief systems "not by recreating forms, rites, or myths," but rather by "creating Western culture from non-Western bases, transforming it and thereby diversifying global contemporary culture" (Mosquera).

Dating back to his childhood, Bedia recalls during our 2005 interview, he was interested in Cuban Indigenous art and exposed to images that frequently appeared in popular Cuban renderings of the Native peoples who inhabited the island, as well as Africans and Creoles (Bedia). Following his introduction to Palo Monte, Bedia began to integrate a wide range of Indigenous and African elements into his work. "I have always been interested in the past," he continues, as well as "the recurrence of elements in various cultures," as seen, for example, in Navajo sand painting or Yaqui masks. "The Yaqui included elements from nearly every group that crossed their path,"

88 For information on Volumen Uno see: www.cubanartnews.org/news/volume_i_or_the_big_bang_ of_contemporary_cuban_art-996/892. See also Weiss.

89 In formulating this concept, Bhabha drew inspiration from Martin Heidegger; see Bhabha $(1,7)$. 
Bedia adds. What has been for the artist an instinctive impulse to incorporate and transform signifies a way of comprehending and interpreting reality, and recognizing and acknowledging what Bedia characterizes as "vital" and "functional" (Bedia).

Although Bedia dismisses any essentialist or universalist notion of culture or human nature, his art strives to put into relief what he terms "certain fundamental truths" or "realities," which continue to be "alive” and "useful." Rather than focusing on contrast, disparity, or distinctions, Bedia seeks verisimilitude, synchronicity and parallelism. His art is cosmopolitan in the truest sense of the word in that it emerges not exclusively from a single root or place of origin, but rather draws inspiration from the many places he has traveled and the cultures and groups he has encountered. "I am searching for archetypal elements," Bedia muses, "which I want to explicate and make my own" (Bedia).

Not unlike his contemporary José Bedia, Leandro Soto addresses fundamental issues regarding displacement, cubanidad, and transculturation through an exploration of Afro-Cuban and Indigenous cultural forms and practices. Soto-who has resided for significant periods of time in various parts of the world, including various locations in Mexico and India, Buffalo (New York), Amherst (Massachusetts), Phoenix (Arizona), and more recently in Barbados and Miami (Florida)-freely aligns African and Afro-Cuban religious symbols with a score of newly acquired elements, which reflect the various cultures and artistic traditions to which he has been exposed in exile. Although he does not actually practice Santería (or Abakuá), the artist's thematically unified series of installations and paintings titled A Glance Over the Garden (1997), for example, was inspired by several conversations with a newly arrived Cuban couple "against the snowy [Buffalo, NY] winter background that covered every garden." Both husband and wife were initiated santeros (practitioners of the AfroCuban religion Santería). "For me as an artist," Soto explains:

it was extremely important to observe how their practices and beliefs were challenged, adapted and transformed by their new environment. New places offer new opportunities, new places to rename, but at the same time they suppress a part of our cultural selves. Elevating the presence of my African ancestors in this collection, as well as the experience of my friends in Buffalo, restores them within the Anglo context of this experience. In effect, I plant "a garden," a garden that functions as a metaphor of living together, of order, and of the appropriation and integration of this new land. (“Cubans” 247)

Leandro Soto's exploration into the relationship between his own cultural roots and Indigenous cultures expanded during his sojourn in Phoenix. In 2005, for example, he created a character called Ireme with the assistance of Cuban artist Nelson García Miranda. ${ }^{90}$ During a performance at the New Contemporary Mesa Center for the Arts in Northern Arizona, Soto created an installation in collaboration with a second

90 Nelson García Miranda actually designed and painted Leandro Soto’s Ireme costume. 
Cuban artist, Dora Hernández. A group of diasporic Cuban drummers, all of whom were living in Arizona at the time, danced and sang in the background as Soto/Ireme danced before a crowd paying homage to the spirits of the dead. The dance took place in front of a palm tree located near the installation. Several members of the audience, who happened to be either Mexican American or Native American, mistook Ireme for a Kachina or Hopi god. Following the performance, they quizzed Soto, assuming that he had confused or crossed what they believed were antithetical cultural elements. To their surprise, Soto revealed that Ireme was actually a Nigerian Abakuá spirit, not a Kachina, and that this spirit was representative of his own ethnic heritage.

Prior to that point, Leandro Soto had been largely unfamiliar with Hopi culture. Despite the distinctly different cultural contexts from which they arose, the similarities between these two divinities were something more than striking. As a result, Soto renamed his performance Kach-Ireme. Commenting on the experience during a personal interview which I conducted in 2005 in Phoenix, he observes, "Cuba is geographically opposite to what we have here in Arizona-it is surrounded by water and green. Being on the island is the opposite of being in the desert. Yet suddenly I was absolutely connected here in Arizona.” This fortuitous discovery led the artist into an exploration of the links among United States Native, Afro-Cuban, Chontales, and Choles cultures (the latter of which he encountered during his five-year tenure in Tabasco, Mexico).

Rather than focusing on difference, Soto-like his contemporary, Bedia-stresses the connective tissues among the Indigenous cultures he has encountered during the course of his journeys. Commenting upon this very subject, he suggests that his work is based on the theory of implosion. In other words, things that are apparently separate are actually interconnected, or interwoven like a tapestry. Deeply influenced by his experience among various Indigenous communities in southern Mexico, such as the Maya-Chol, Soto adopted a cosmopolitan worldview that conceives of reality as an intricate tapestry of transpersonal or infinite energies woven together by some divine force or spirit. He sees the trajectory of his travels as a cumulative process in which he is continually editing and re-editing his earlier experiences. "They are all connected," he assures me. Commenting on his own work, Soto explains:

I work with the complexity of being Caribbean, a culture heritage that is composed of diverse cultural presences. In order to nourish these expressions, I have done a lot of anthropological research in the countries and cultures where I lived. I have used the term "cultural translation" to talk about this process. I insist that I should become part of the communities in which I reside at a particular moment of my life. In order to become a "channel" (artist-shaman), for this community, I have to work with a trans-personal thematic and trans-personal issues. ... In my view, that which is apparently dispersed or diffuse is also linked to the magical, that is, I hold a vision of the world where reality is conceived as a tapestry of transpersonal energies. (Soto, "De Palo pa’ Rumba” 168-169) 
Resonant with Bedia's practice, Soto emphasizes a concept he refers to as religare. Drawn from a Latinate tradition, this term signifies reunion, re-connection, re-integration, and communion-something that the artist characterizes as a non-Western, cosmopolitan approach to reality and creative expression (Personal interview; "De Palo pa' Rumba” 170). The works featured in Soto's installation project A Glance Over the Garden or paintings referencing the orishas or deities, such as Oggun's Chair, are visible manifestations of the heterogeneous and chameleonic aspects of Cuban culture given its long history of cultural intermixing and collision. ${ }^{91}$ In a discussion of these aspects of Cuban culture, with specific reference to the orisha Eleguá92 (one of his later installations inspired by the exhibition in Buffalo), Soto discussed the verisimilitude of visual elements:

A good example of this cultural integration is the installation I devote to [the orisha] Eleguá-the god of new paths and avenues. I used maps of the routes I followed to go from Miami (my point of entrance in this country) to the Northeast of the United States (where I resided for a number of years). I displayed an image of Mickey Mouse-red and black, Eleguá's colors-as part of this installation because a mouse is Eleguá's favorite animal! Thus, Mickey Mouse-who is black and red and a mouse to boot-is the perfect cultural object to explain and visually translate Eleguá Laroye. Also, I displaced a small version of the Statue of Liberty from its original location in New York City to the Miami area since, for many exiled Cubans, Miami is the most important city in the United States. I also used envelopes-black and red-from the United States mail overnight service in order to provide color and content for this installation. (“De Palo pa' Rumba” 173-174)

Soto's installations reconstitute and invoke a pantheon of orishas through familiar, iconic objects and images drawn primarily from United States popular culture. In liberally pairing the sacred with the profane, Soto suggests the integral and synergistic relationship between these two realms. In this sense, his installations blur the lines traditionally drawn between the supernatural and the natural. According to the artist's view, art is de palo pa' rumba-a popular Cuban expression that refers to a sudden change in topic or theme during a conversation. Taken in more literal terms, it refers to a shift in conversation from the subject of Palo Monte ${ }^{93}$ (the sacred) to rumba (the secular or profane). Put another way, this expression suggests the co-existence of, and hidden links among, seemingly antithetical elements. ${ }^{94}$

Soto's thoughtful juxtaposing and counterbalancing of apparently contrasting objects endows them, as Cuban art critic Tony Morales observes, with "the quality of expressing some universal principles emanating from a local perspective"; these

91 For more information on the orisha Oggun, see: santeriachurch.org/the-orishas/ogun/.

92 For more information on Eleguá, see: santeriachurch.org/the-orishas/eleggua/.

93 Palo-also known as Las Reglas de Conga-is an Afro-Cuban religion that developed among slaves from the Congo Basin. Monte, Mayombe, Briyumba and Kimbisa are all autonomous branches of Palo. 94 For more on this subject, see Soto ("De Palo pa' Rumba” 169). 
principles ultimately bespeak the cosmopolitan aspects of his art. ${ }^{95}$ They suggest, moreover, the integrative and mediatory role the artist plays in congregating these elements. Soto's creations-like Bedia's-invoke the most fundamental tenets of the various religious traditions that he draws from and allude to what the artist characterizes as "the all-embracing nature" of Cuban culture itself, for they simultaneously capture or make visible the "integral relationships" among seemingly antithetical objects and recapture some essential essence, which the vanguardia or modernist artists first recognized as being fundamentally Cuban.

My interpretation of the work of diasporic artists such as José Bedia and Leandro Soto puts into relief the links that exist among the social and political, the spatial and temporal, and the historical and cultural. In turn, this approach highlights the idea that just as Bedia and Soto visually reconstitute the self in diaspora, they produce or construct alternative cartographies in the process of recreating and reimagining space. ${ }^{96}$ An overarching challenge in approaching the work of the $C A F E$ artists lay in addressing the paradoxical notion that historical and cultural continuity coexist in their art alongside movement, variation, and change. In this respect their art testifies to the idea Stuart Hall first proposed that "difference always resides alongside continuity."97 The discourses of diaspora, James Clifford and Hall insist, must be modified and adapted when speaking about the experiences of the displaced, the "unhomed," or desterrados. "What is at stake," Clifford points out, "is a comparative cultural studies approach to specific histories, tactics, everyday practices of dwelling and traveling: traveling-in-dwelling, dwelling-in-traveling” (qtd. in E. G. Anderson 187).

An attendant difficulty in interpreting the work of artists such as Bedia and Soto lay in the need to smith vocabulary elastic enough to capture these seemingly antithetical and protean aspects of their art without losing meaning altogether. As I suggest at the outset of this chapter, the Cuban diasporic experience has been structured rhetorically according to a bi-cameral and binary demarcation of home

95 For more information, see Tony Morales's "A Glance Over the Garden," which is featured in the pamphlet distributed by Bit Orbit Gallery for the exhibition (September 20-October 25, 1997).

96 The French sociologist and philosopher Henri Lefebvre was one of the first theorists to explore what he termed the production of space. In The Production of Space (Blackwell, 1991), Lefebvre questioned the binary logic of how we understand spatiality, and proposed a concept of spatial variability that examined the relationship among historicality, sociality, and spatiality. Among other things, Lefebvre considered the multiple meanings of space and the interplay between the social and the spatial. Lefebvre's concepts were expanded upon by theorists such as Michel Foucault, Michel de Certeau, and Jean Baudrillard, as well as more contemporary scholars such as Dorothy Hayden, Doreen Massey, Monika Kaup, and Mary Pat Brady. Other prominent figures engaged in re-envisioning traditional concepts of spatiality include Edward W. Soja, Gayatri Spivak, Edward Said, Homi K. Bhabha, bell hooks, Gloria Anzaldúa, and Trinh Minh-ha.

97 Paul Gilroy uses this phrase throughout The Black Atlantic: Modernity and Double Consciousness. I am adapting Stuart Hall's claim that "Difference ... persists-in and alongside continuity” (Hall 228). 
and nation. ${ }^{98}$ In the process, the misleading dichotomy of island and diaspora, of the here/aqui and the there/alli, has been established. The emphasis in much Cuban diasporic discourse and cultural expression, therefore, has been on territorial claims to both nationhood and culture. On the contrary, I apply a relational, multi-axis analysis in order to capture the movement of cultures across borders. "A relational analysis," Ella Shohat observes, "address[es] the operative terms and axis of stratification typical of specific contexts, along with the ways these terms and stratifications are translated and reinvoiced as they 'travel' from one context to another" (11). The particular theoretical approach to diasporic identity formation and cosmopolitical cultural exchange intentionally moves away from definitions or theoretical paradigms that regard mobility and stability as mutually exclusive terms, or privilege stasis over mobility. "The person who finds his homeland sweet," Hugh of St. Victor tells us, "is still a tender beginner; he to whom every soil is as his native one is already strong; but he is perfect to whom the entire world is as a foreign place. The tender soul has fixed his love on one spot in the world; the strong person has extended his love to all places; the perfect man has extinguished his" (qtd. in Said, Culture 335). ${ }^{99}$ In emphasizing the positive aspects of movement and trans-locality, Hugh of St. Victor defies a host of conventional Western assumptions regarding territoriality and nationhood. Rather than stressing loss or displacement and casting them in a negative light, he celebrates the fundamentally cosmopolitan ideal of the individual who belongs-at once-everywhere and nowhere as powerful and free.

For $C A F E$ artists such as Bedia and Soto, movement functions as a mode of cultural survival as well as a potent form of resistance. It signifies, moreover, accumulated knowledge, and oftentimes serves as a source of creative potential, or grace under pressure, as Soto often suggests (riffing on Ernest Hemingway). Inspired by Hugh of St. Victor, my critical and creative work examines the strategic advantages of multi- or trans-local cosmopolitanism without diminishing the devastating and oftentimes violent aspects of rupture and displacement, or ignoring what Edward Said characterizes as "disorienting loss" or "the crippling sorrow of estrangement" ("Reflections"). It proposes an alternative or altered concept of nomadism, which suggests a kind of weightlessness or detachment from physical space (to borrow Frank and Gumbrecht's concepts once again), and at the same time posits what Nicolas Bourriaud characterizes as a radicant approach to identity-i.e., the idea of being rooted in multiple places. ${ }^{100}$

98 Brent Hayes Edwards makes the same point in his entry "Diaspora" in Keywords for American Cultural Studies.

99 Hugh of St. Victor was a medieval philosopher, theologian, and mystical writer born in Saxony, France in 1096. A colleague pointed out his quotation after learning about my project.

100 In The Radicant Bourriaud discusses at length the manner in which a radicant aesthetic is unlike Gilles Deleuze and Félix Guattari's concept of the rhizome (first developed in A Thousand Plateaus: Capitalism and Schizophrenia, U of Minnesota P, 1987). Noting the rhizome's non-hierarchical and 
Though nomadism is generally understood as "dispens[ing] altogether with the idea of a fixed home or center," it is traditionally defined as a state of being "without the hope or dream of a homeland" (Durham). The aesthetic formula of nomadism that I propose recasts this definition. It is liberating, on the one hand, in its emphasis on movement and detachment-much like Hugh of St. Victor's concept and akin to the Taoist notion of impermanence or indifference to the world.

Despite its insistence on itinerancy and transience, this particular approach to nomadism is also grounded in a concept of doubleness that involves rooting and rerooting, continuity, and as Frank puts it, the simultaneous elimination and recuperation of space. It permits, moreover, a form of rooted cosmopolitanism (to use Kwame Anthony Appiah's notion) that enables diasporic subjects to also transport their roots and thereby remain connected to their homeland. In other words, the migratory diasporic figures live what Said termed a contrapuntal life, in which the condition of spacelessness is simultaneously and paradoxically rooted to, and detached from, particular spaces-places (Appiah).

Cuban culture and all of its expressions is, and always has been, simultaneously portable and solidly grounded. ${ }^{101}$ Reflecting this aspect of the Cuban condition, the phrase setting the tent against the house (the subtitle of the study) thus envisions the

fluid structure, as well as its interconnected significations, Bourriaud nevertheless distinguishes this image from the radicant by pointing out that "unlike the rhizome, which is defined as a multiplicity that brackets out the question of the subject from the beginning, the radicant takes the form of a trajectory or path; the advance of a singular object. ... The radicant implies a subject, but one that is not reducible to a stable, closed, and self-contained identity. It exists exclusively in the dynamic form of its wandering and the contours of the circuit it describes, which are two modes of visibility. In other words, it is movement that ultimately permits the formulation of an identity ... [it] views the self as constructed out of borrowings, citations, and proximities ... [and] differs from the rhizome in its emphasis on the itinerary, the path, as a dialogical or inter-subjective narrative that unfolds between the subject and the surfaces it transverses, to which it attaches its roots to produce what might be termed an installation: one 'installs oneself' in a place or situation in a makeshift or precarious way, and the subject's identity is nothing but the temporary result of this encampment, during which acts of translation are performed. Translation of a path into a local language, translation of oneself into a milieu-translation in both directions. Thus, a radicant subject appears as a construction or montage, in other words, as a work born of endless negotiation" (Bourriaud 55-56).

101 As Eric Gary Anderson points out in a discussion of American Indian space, temporality, and movement, "migrations are, paradoxically, constants" in many cultures, though all native groups are deeply tied to the earth. The idea that movement is a mode of survival-that movement is knowledge and power-is an ancient concept that defies conventional Western concepts regarding property or ownership, and is widely embraced by many Native-American groups. While discussing this topic, a colleague pointed out that a critical difference between the Native experience and that of diasporic Cubans is the idea that many Cubans cannot return to their native land, whereas nomadic Native American groups generally followed seasonal migration patterns in order to locate food sources. As a result, they often returned to the same locations. Nevertheless, when read in the context of relocation, one can imagine the parallels that can be drawn among these groups (E. G. Anderson 17). 
island and its culture as a moveable tent, as opposed to the stationary concept of a house or home. In this way, it strives to extinguish the urge to locate one's understanding of culture and nation in one spot in the world..$^{102}$

Finally, general principles expressed in quantum physics offered me new ways to think about the weightless aspects of cosmopolitical diasporic identifications and expressions, for certain threads of its particular discourse admit the possibility that multiple "realities" or states of being can co-exist. ${ }^{103}$ This theory relies on a concept of non-locality that is less concerned with determining the exact physical location or state of a particle or an object at any given moment, but rather focuses upon the probability of where it might or can be located in both physical and temporal terms.

As previously suggested, the diasporic condition operates on the quantum principles of trans-locality and positionality. Loosely akin to the concept of non-locality, the identifications that artists such as Bedia and Soto assume and the conceptual spaces they inhabit are multiple. At the same time, as I have suggested early on, their understanding of self is always measured inadvertently against the absent-presence that is the island. In this sense their art simultaneously signifies and collapses the geographical distances that represent the here and the there, and thereby presents an uncanny repetition of the island, to borrow Benítez-Rojo's concept (Benítez-Rojo), which defies traditional cartographical conventions regarding spatiality.

Recent trends in quantum thought also posit the notion that "something that happens now is affected by something that happens in the future" (Jeff Tollaksen, qtd. in Begley). This possibility bespeaks the sense of contemporaneity or cross-temporality implicit in individual diasporic artists' work and the various presentations of $C A F E$, for each heralds the future at the same time that it invokes both the present and the cultural and historical past. These collective aspects of quantum thought-of an infinitely malleable idea of interstitial spatiality, contemporaneous existence and momentum, and the possibility that the present and the future not only interface but overlap-have allowed me to rethink and problematize what one critic terms EuroAmericans" "imaginary constructions of space, land, time, and history" (E. G. Anderson 38).

The rich and diverse cultural expressions of diasporic artists such as José Bedia and Leandro Soto are at the juncture of seemingly antithetical social locations and perspectives, thereby playing simultaneously on difference and similarity. In this sense,

\footnotetext{
102 I am consciously appropriating Richard Kearney's term, which appears in the title of his critical work Postnationalist Ireland: Politics, Culture, Philosophy. In the same vein, I am borrowing Harry Berger, Jr.'s phrase set the house against the tent, which is quoted in and drawn from a discussion of the Mosaic and Davidic covenants in Boyarin and Boyarin (105).

103 The quantum version of the double- or two-slit experiment, in which a single photon is seen as passing through two slits in a screen simultaneously, provides a good example, as does the paradoxical thought experiment Schrödinger's Cat.
} 
they put into relief the complex nature of all cultural expressions and productions (Hall 228-229). When applied as a theoretical framework, an open-ended and fluid approach to diasporic art allows for a more malleable and improvisational discourse, which re-inscribes at the same time that it transforms, and thereby circumvents any notion of a homogeneous or uniform imagined community (B. Anderson), or a fixed "idea" of nation or culture. It is post-nationalist and cosmopolitan in that it extends beyond what Homi Bhabha refers to as the "paradigmatic colonial and postcolonial condition of being unhomed," for "home" in the context of diaspora is always, simultaneously, here and elsewhere (B. Anderson 13). The way to locate Cuba, therefore, is not simply by fixing one's gaze on the island, but as Tagore suggests, by knocking on others' doors.

\section{Works Cited}

Anderson, Benedict. Imagined Communities. Verso, 1991.

Anderson, Eric Gary. Indian Literature \& the Southwest: Contexts and Dispositions. U of Texas P, 1999.

Appiah, Kwame Anthony. "Cosmopolitan Patriots." Cosmopolitics: Thinking and Feeling Beyond the Nation, edited by Pheng Cheah and Bruce Robbins, U of Minnesota P, 1998, pp. 91-114.

Bedia, José. Personal interview. 13 Nov. 2007.

Begley, Sharon. "Putting Time in a (Leaky) Bottle." Newsweek, 30 July 2007, p. 49.

Benítez-Rojo, Antonio. The Repeating Island: The Caribbean and the Postmodern Perspective. Duke UP, 1996.

Bhabha, Homi K. The Location of Culture. Routledge, 1994.

Bourriaud, Nicolas. The Radicant. Lucas and Sternberg, 2009.

Boyarin, Daniel, and Jonathan Boyarin. "Diaspora: Generation and the Ground of Jewish Identity." Theorizing Diaspora, edited by Jana Evans Braziel and Anita Mannur, Blackwell, 2005, pp. $85-118$.

Cheah, Pheng, and Bruce Robbins, editors. Cosmopolitics: Thinking and Feeling Beyond the Nation. U of Minnesota P, 1998.

Clifford, James. "Diasporas." Routes: Travel and Translation in the Late Twentieth Century. Harvard UP, 1997, pp. 244-277.

Durham, John Peter. "Exile, Nomadism, and Diaspora: The Stakes of Mobility in the Western Canon." Home, Exile, Homeland, Film, Media and the Politics of Space, edited by Namid Naficy, Routledge, 1999, pp. 18-41.

Frank, Søren. Salman Rushdie: A Deleuzian Reading. Tusculanum P, 2011.

--.. "Globalization, Migration Literature, and the New Europe." Cosmopolitanism and the Postnational: Literature and the New Europe, edited by Cesar Dominguez and Theo D'haen, Brill-Rodopi, 2015, pp. 107-130.

Gilroy, Paul. The Black Atlantic: Modernity and Double Consciousness. Harvard UP, 1993.

Gumbrecht, Hans Ulrich. "A Negative Anthropology of Globalization.” The Multiple Faces of Globalization, edited by Francisco González, BBVA, 2009, pp. 230-241.

Hall, Stuart. Cultural Identity and Diaspora: Identity, Community, Culture and Difference. Lawrence \& Wishart, 1990. 
Hayes Edwards, Brent. “Diaspora.” Keywords for American Cultural Studies, edited by Bruce Burgett and Glenn Hendler, New York UP, 2007, p. 83.

Kearney, Richard. Postnationalist Ireland: Politics, Culture, Philosophy. Routledge, 1997.

Mosquera, Gerardo. "The Infinite Island: Introduction to New Cuban Art." Contemporary art from Cuba: irony and survival on the utopian island: Arte contemporáneo de Cuba: ironía y sobrevivencia en la isla utópica, edited by Marilyn A. Zeitlin, Arizona State U Art Museum, 1999.

O'Reilly Herrera, Andrea. Cuban Artists Across the Diaspora: Setting the Tent Against the House. U of Texas P, 2011.

--.. ReMembering Cuba: Legacy of a Diaspora. U of Texas P, 2001.

--.. The Pearl of the Antilles. Bilingual Review P, 2001.

---, editor. Cuba: Idea of a Nation Displaced. SUNY P, 2007.

Pau-Llosa, Ricardo. "Identity and Variations: Cuban Visual Thinking in Exile Since 1959." Outside of Cuba/Fuera de Cuba, edited by lleana Fuentes-Pérez et al., Rutgers UP, 1988, pp. 41-63.

Rushdie, Salman. Shame. 1983. Vintage, 1995.

--.. "Step Across This Line." Step Across This Line: Collected Nonfiction 1992-2002. Random House, 2002, pp. 347-381.

Safran, William. "Diasporas in Modern Societies: Myths of Homeland and Return." Diaspora, vol. 1, no. 1, 1991, pp. 83-99.

Said, Edward. Culture and Imperialism. Knopf, 1993.

--.. "Reflections on Exile." Reflections on Exile and Other Essays. Harvard UP, 2000, pp. 173-186.

Shohat, Ella. "Gendered Cartographies of Knowledge." Taboo Memories, Diasporic Voices, Duke UP, 2006.

Soto, Leandro. "Cubans in the United States: An Example of Ethnic Identity in the Making." ReMembering Cuba: Legacy of a Diaspora, by Andrea O'Reilly Herrera, U of Texas P, 2001, pp. 245-247.

--. “De Palo pa' Rumba: An Interview with Leandro Soto," by Isabel Alvarez Borland, Afro-Hispanic Review, vol. 26, no. 1, Spring 2007, pp. 167-178.

--.. Personal interview. 20 May 2005.

Weiss, Rachel. To and From Utopia in the New Cuban Art. U of Minnesota P, 2010. 